\title{
Research Note Inflation: An understanding and its impact on indigenous economy
}

\section{口 Rashmi}

Correspondence to :

\section{Rashmi}

Department of Agricultural

Economics, Institute of

Agricultural Sciences

(BHU), Varanasi

(U.P.) India

Email : rash6222@

gmail.com

Paper History :

Received : 22.12 .2018

Accepted : 28.02.2019

\section{KEY WORDS : Inflation, Understanding, Impact, Indigenous economy}

How To Cite This PAPer : Rashmi (2019). Inflation: An understanding and its impact on indigenous economy. Internat. Res. J. Agric. Eco. \& Stat., 10 (1) : 171-174, DOI : 10.15740/HAS/IRJAES/10.1/171-174. Copyright@ 2019: Hind Agri-Horticultural Society.
Growth with stability is essential condition for procuring sustainable economic development. Fluctuation in prices engenders an atmosphere of dubiousness which is not conducive to development. An economy when marked by sustained increase in the general price level of goods and accommodations is verbally expressed to be experiencing inflation. It is one among those factors which engenders imbalance in the economy. The term inflation is derived from a Latin word "Inflare" which betokens 'blow into'. Hence, the blown up prices in economy is termed inflation but, it does not just only denote elevating prices, it signifies that there is more mazuma in the economy chasing same number of goods and accommodations. Owing to this phenomenon of too few goods being chased by an exorbitant amount of mazuma the authentic value of mazuma gets diluted i.e. loss in purchasing power of mazuma. Albeit economists often argue that a mild rate of inflation (3-5\%) is auspicious for an economy as it engenders an environment for investment resulting in more immensely colossal income and full employment. The rate at which prices of commodities elevate is termed as inflation rate. For instance, if price of a commodity is Rs. 50 this year and next year the price elevates to Rs.54, then rate of inflation is 4 per cent. This inflation rate which is an annualized percentage transmutation in a general price index is quantified by consumer price index (CPI) or wholesale price index (WPI). CPI is preferred these days as it measures the cost of consuming a standard basket of goods and accommodations over a particular period, hence, is representative of cost of living in a particular economy, thereby giving a better picture of effect of inflation.

Inflation is not incipient to the modern world, it dates back to the third century when Roman rulers experienced inflation for the first time due to debasing their coins. China suffered from inflation in fourteenth century when emperors superseded coins with paper mazuma. Western 